\title{
MIESZKALNICTWO W DYDAKTYCE
}

\author{
Agnieszka Kłopotowska ${ }^{1}$, Maciej Kłopotowski² \\ ${ }^{1}$ Zakład Urbanistyki i Planowania Przestrzennego, Wydział Architektury, \\ Politechnika Białostocka, e-mail: a.klopotowska@pb.edu.pl
}

\begin{abstract}
${ }^{2} Z$ Zespół Dydaktyczny Architektury Krajobrazu, Katedra Ochrony i Kształtowania Środowiska, Wydział Budownictwa i Inżynierii Środowiska, Politechnika Białostocka, e-mail: m.klopotowski@pb.edu.pl
\end{abstract}

\begin{abstract}
Streszczenie: Na Wydziale Budownictwa i Architektury Politechniki Lubelskiej nauczanie projektowania obiektów - miejsc zamieszkania stanowi wieloetapowy proces dydaktyczny, obejmujący trzy podstawowe zadania projektowe (mieszkanie, dom, budynek wielorodzinny). Przy ich realizacji każdorazowo poszerzany jest zakres problemowy, stopień opracowania technicznego oraz graficznego projektu. Obiekty mieszkalne (o zróżnicowanej funkcji i wielkości) są również często wybieranym tematem prac dyplomowych na poziomie inżynierskim i magisterskim. Poniżej przedstawiono metodologię nauczania tych zagadnień W Politechnice Lubelskiej.
\end{abstract}

Słowa kluczowe: budynek wielorodzinny, dom atrialny, dom jednorodzinny, mieszkanie, zespół domów jednorodzinnych, zabudowa wielorodzinna.

\section{WPROWADZENIE}

Mieszkalnictwo to architektoniczna codzienność - powszechność w życiu odbiorcy i w pracy architekta. Janusz A. Włodarczyk w książce Żyć znaczy mieszkać pisze: „Dom mieszkalny jest zagadnieniem projektowym dla architekta niewdzięcznym, w pewnym sensie dziwnym; niby prostym, skoro może go zrobić (zaprojektować, wykonać) każdy, a więc również laik. Projektują je zgodnie z prawem pseudo - specjaliści nie będący architektami. Doświadczeni architekci uważają, że zaprojektowanie dobrego domu mieszkalnego jest zagadnieniem trudnym, (...)" , zaś Marian Fikus rozważając tę kwestię dodaje: „Absolutnie architektura domu rodzinnego jest specyficznym, szczególnym zadaniem projektowym, nieporównywalnym z żadnym innym. Użyte dwa razy „a” na początku zdania ma tę szczególność podkreślić jak $\mathrm{W}$ ogłoszeniach gazetowych. $\mathrm{Z}$ całą pewnością jest to architektura najbardziej powszechna, z całą też pewnością najbardziej odpowiedzialna, gdyż dotyka bezpośrednio życia grupy ludzi i jej najważniejszych potrzeb egzystencjonalnych odniesionych zarówno do bytu fizycznego, jak i emocjonalno - duchowego."2 Dom kontekście powyżej prezentowanych poglądów jawi się zatem jako zadanie szczególne, wyjątkowe, niemalże przygoda intelektualna. Obiekt z jednej strony banalny, z drugiej fascynujący. Obiekt stosunkowo mały - w kategoriach gabarytowych i jednocześnie skomplikowany funkcjonalnie. Powszechny a mający szanse na wejście do kanonu estetycznego naszej kultury³.

1 Włodarczyk Janusz A.: Żyć znaczy mieszkać. Dom naszych pragnień i możliwości, Wydawnictwo Naukowe PWN, Warszawa - Kraków 1997, s. 140.

2 Wypowiedz Mariana Fikusa z: Dom przyszłości. Konkurs Wydawnictwa MURATOR i Fundacji DOM DOSTĘPNY. Praca zbiorowa pod redakcją Małgorzaty Wilamowskiej. Wydawnictwo MURATOR, Warszawa 2000, s. 5.

3 Nie wyobrażamy sobie przecież historii architektury bez takich współczesnych dzieł jak: dom Schrődera Gerrit Rietvelda (1924), dom Konstantina Mielnikowa (1927-29), Willi Savoye Le Corbusiera i Pierre Jeannerta (1929-31), dom w Plano Ludwiga Miesa van der Rohe (1946-51), dom Kaufmana w Palm Springs Richarda Neutry (1946-47), Szklany dom Phillipa Jonsona (1949), dom Vanny Venturi Roberta Venturiego (1962-64), Willa Zapu Davida Connora (1984), dom Rudin Jaquesa Herzoga (1997), oraz domów: Franka Lloyda Wrighta, Antonia Gaudiego, Josepha Olbrichta, Charlesa Mackintosha, Alvara Aalto, Petera Eisenmanna, Richarda Meiera, Christophera i Timothy Morris, Franka Gehrego, Mario Botty, Davida Lea, itd..., a przecież to tylko domy - AŻ DOMY, chciałoby się krzyknąć. 
Z tego też względu mieszkalnictwo to jeden z najważniejszych obszarów kształcenia studentów w szkołach architektury na całym świecie. Nauczanie projektowania mieszkań, domów i budynków wielorodzinnych przyjmuje różne formy i realizowane jest w różnym wymiarze godzinowym. Każdorazowo jego nadrzędnym celem jest uzyskanie przez przyszłych projektantów kompetencji praktycznych. Składają się na nie: umiejętności kształtowania układów funkcjonalnych budynków mieszkalnych oraz kształtowania ich form architektonicznych. Zagadnienia te należy rozwinąć również o skomplikowane zadania z zakresu projektowania zespołów domów w różnej skali. Niezbędnymi elementami w tym procesie edukacji są jej podstawy - prerekwizyty, na które składają się nauki społeczne, takie jak: psychologia i socjologia, oraz techniczne takie jak: ergonomia, budownictwo i grafika inżynierska. Podstawową sukcesu (zdobycia przez studenta zakładanych umiejętności) w procesie kształcenia $\mathrm{w}$ tym obszarze jest jego etapowanie i kolejne, systematyczne poszerzanie wiedzy studenta. $\mathrm{Na}$ Wydziale Budownictwa i Architektury Politechniki Lubelskiej proces ten podzielono na trzy kursy: mieszkanie, dom i budynek wielorodzinny. Poprzedzają je podstawy ergonomii. Cykl dydaktyczny może być również kontynuowany dzięki projektom dyplomowym na I i II stopniu studiów.

\section{DYDAKTYKA WSPIERAJĄCA KSZTAŁCENIE W OBSZARZE MIESZKALNICTWA}

\section{ERGONOMIA (SEMESTR I)}

Dydaktycy kształcący w tym obszarze stawiają sobie za cel przekazanie studentowi wiedzy na temat związku pomiędzy człowiekiem i elementami otaczającej go przestrzeni biotycznej i abiotycznej. Ponadto wykształcenie w studencie potrzeby dostosowania wszystkich elementów otoczenia zewnętrznego do jego wymiarów i uwarunkowań percepcyjno - ruchowych człowieka. Absolwent po skończonym kursie rozumie zatem zależności pomiędzy budową anatomiczną i przestrzenią ruchową człowieka a jego otoczeniem zewnętrznym. Potrafi je również określić i zaprojektować formy przestrzenne dostosowane do parametrów fizycznych konkretnych osób, a także określić parametry przestrzeni stref niezbędnych do wykonywania konkretnych czynności. Proces dydaktyczny prowadzony jest na tle uwarunkowań filozofii różnych epok, zaś zadanie dydaktyczne polega na zapoznaniu studenta $\mathrm{z}$ kanonami estetycznymi i wykształceniu w nim świadomości ich zmienności oraz związku z duchem czasu. W czasie trwania zajęć student opracowuje szereg ilustracji - odpowiedzi na jednostkowe zadania projektowe. Część z nich związana jest z przestrzenią wewnętrzną w obiektach mieszkalnych i meblami. Wiedza i umiejętności zdobyte w tym zakresie są bazą dla prac projektowych realizowanych na kolejnych etapach edukacji.

Psychologia i socjologia. Wplecione są w cały tok nauczania na kierunku architektura. $\mathrm{W}$ zakresie mieszkalnictwa poszerzane są one o zagadnienia $\mathrm{z}$ obszaru kulturoznawstwa. Celem dydaktyki w tym obszarze jest przekazanie studentowi wiedzy o ludzkich zachowaniach w przestrzeni, zarówno wewnętrznej jak i zewnętrznej, modelach korzystania z niej oraz o problemach i konfliktach, które mogą powstawać na skutek złego jej zaprojektowania.

\section{BUDOWNICTWO I GRAFIKA INŻYNIERSKA}

Zasadniczy proces kształcenia $\mathrm{w}$ toku studiów w tym obszarze stanowią odrębne ścieżki dydaktyczne. Niezależnie od nich każdy z przedmiotów projektowych, w tym wszystkie z obszaru mieszkalnictwa, mają przyporządkowane sobie zadania dydaktyczne z tego zakresu. Kolejne następujące po sobie zadania projektowe są rozwiązywane z coraz większą dokładnością techniczną - od umownej, ogólnie określającej parametry elementów budowlanych, do szczegółowej - pokazującej detale techniczne konkretnych rozwiązań. Grafika przekazu 
opracowań projektowych również ulega rozwojowi, od odręcznych schematów i szkiców, do komputerowych rysunków i wizualizacji.

\section{MIESZKANIE (SEMESTR II)}

Kształcenie w zakresie mieszkalnictwa rozpoczyna kurs Projektowanie mieszkań. Studenci w czasie jego trwania poznają typologię mieszkalnictwa oraz podstawowe parametry i współczynniki, które je charakteryzują. Ponadto wprowadzani są w zagadnienia związane z podstawami uwarunkowań psychologicznych i kulturowych mieszkalnictwa w Polsce oraz innych krajach. Służą temu między innymi zajęcia seminaryjne, w czasie trwania których omawiane są tradycyjne domy: polskie, angielskie, amerykańskie, arabskie, chińskie, japońskie i inne. Zapoznawani są również ze wzorcami socjologicznymi rodzin oraz zasadami kształtowania rzutu mieszkania, z uwzględnieniem indywidualnych preferencji mieszkańców.

Zadanie semestralne studenci rozpoczynają od ćwiczenia klauzurowego „Dom moich marzeń”. Stylistyczna różnorodność prac, będąca jego wynikiem, pozwala uzmysłowić przyszłym architektom wielość „poglądów estetycznych”, które mogą reprezentować ich przyszli klienci. Uzmysławia im również potrzebę weryfikowania własnych poglądów, które w przyszłości kształtować będą ich credo projektowe.

Opracowanie projektowe realizowane w czasie zajęć na semestrze II to parterowy dom atrialny. Jego program użytkowy ma zaspakajać potrzeby czteroosobowej rodziny (rodzice z dwójką dzieci). Studenci opracowują rzut mieszkania oraz sporządzają aranżację meblową wszystkich pomieszczeń. Zadanie to wymaga połączenia wiedzy technicznej z zakresu mieszkalnictwa, ergonomii oraz nauk społecznych. Projekt sporządzany jest na siatce modularnej wielkości $60 \times 60 \mathrm{~cm}$. Użycie jej pozwala na zdobycie umiejętności posługiwania się modułem przestrzennym oraz łatwe ,skalowanie” mebli, elementów budowlanych i przestrzeni ruchowej człowieka. Z uwagi na specyficzny model domu atrialnego jego architektura w sensie wyrazu plastycznego jest zwykle skromna i powściągliwa. Odpowiada ona rzeczywistym wzorcom, przykładom zaczerpniętym z realizacji z obszaru Danii, Francji, Niemiec, Szwecji i Polski, które studenci poznają podczas wykładów. W toku dyskusji na temat problemów plastycznych zabudowy dywanowej autorzy opracowań zachęcani są do poszukiwania rozwiązań zindywidualizowanych, mieszczących się jednak w spójnej konwencji stylistycznej. Kształtując wielomodułowe pierzeje zabudowy atrialnej w praktyce stosują pojęcie rytmu i akcentu.

Dom atrialny traktowany jest jako element strukturalny zespołu mieszkaniowego. W oparciu o przegląd zrealizowanych układów zabudowy dywanowej, w wyniku dyskusji studenci wypracowują model i program takiego założenia. Zwykle składa się on z kilkunastu jednostek, skupionych wokół wspólnego terenu rekreacyjnego. Jednostki te obsługiwane są komunikacją obrzeżną. Stanowiska postojowe lub garażowe oraz miejsca gromadzenia odpadów stałych projektowane są jako odrębne miejsca. $Z$ uwagi na fakt, iż projekt ten wyprzedza kursy z budownictwa, rozwiązania materiałowe i konstrukcyjno - budowlane w opracowaniach studenckich przedstawiane są w sposób schematyczny. Gabaryty proponowanych rozwiązań muszą jednak każdorazowo odpowiadać rozwiązaniom rzeczywistym.

Opracowania projektowe sporządzane są w sposób tradycyjny, bez użycia technik komputerowych. Studenci nabywają przy tym umiejętność wzajemnego odnoszenia rzutów, przekroi i elewacji. Planszom prezentacyjnym towarzyszy model w skali 1:50, prezentujący wnętrze domu z jego podstawowym wyposażeniem.

Wymiernym efektem zadania projektowego (na które składa się projekt koncepcyjny nieskomplikowanego parterowego domu jednorodzinnego) jest zdobycie umiejętności sporządzania prawidłowego schematu układu funkcjonalnego. Umiejętność ta jest bazowa dla kolejnych opracowań projektowych sporządzanych w dalszym toku studiów. Po ukończeniu kursu student potrafi również sporządzić prawidłowy projekt koncepcyjny zespołu domów jednorodzinnych, uwzględniający aspekty społeczne i odpowiadającą im hierarchizację 
przestrzeni. Ponadto w wyniku licznych korekt student nabiera umiejętności rozmowy na temat własnego opracowania. W sposób logiczny i uporządkowany potrafi przedstawić własne decyzje projektowe, omówić je w sposób wyczerpujący oraz argumentować ich słuszność w konkretnych sytuacjach projektowych.

\section{DOM JEDNORODZINNY (SEMESTR III)}

Wolno stojący dom jednorodzinny nadal stanowi najbardziej pożądany model zamieszkiwania w Polsce. Umiejętność jego prawidłowego projektowania, na uczelniach kształcących w obszarze architektury, objęta jest zatem odrębnym kursem dydaktycznym. Uczestnicząc w nim student poszerza swą wiedzę o zagadnienia związane $\mathrm{z}$ funkcjonowaniem rozbudowanego układu przestrzennego. Poznaje również programowo - przestrzenne metody zaspakajania indywidualnych potrzeb użytkowników. Wśród zagadnień z obszaru teorii architektury jako istotne pojawiają się problemy nasłonecznienia, przewietrzania i wentylacji domu. Studenci zapoznawani są również z przepisami prawa, determinującymi rozwiązania projektowe w naszym kraju. Dotyczą one w znacznej mierze zagospodarowania działki budowlanej. Kurs rozpoczyna dyskusja o domu ,idealnym”, która prowadzona jest w oparciu o prace studentów.

Projekt każdorazowo opracowywany jest indywidualnie, na konkretnej (choć często jedynie teoretycznej działce), zlokalizowanej w określonym kontekście przestrzennym. Architektura proponowanych rozwiązań z założenia ma być spójna z otoczeniem architektonicznym. W tym celu kontekst zostaje dokładnie sprecyzowany i ustalany na podstawie znanych współczesnych realizacji architektonicznych. Dom projektowany jest dla fikcyjnej czteroosobowej rodziny, której potrzeby student sam definiuje. Przyporządkowanie poszczególnym członkom rodziny: wieku, zawodu, zainteresowań, preferowanych form rozrywki i sposobu spędzania czasu wolnego pozwala dokładnie sprecyzować zapotrzebowania przestrzenne.

Zakres zagadnień teoretycznych obejmuje również pojęcie standardu, które student poznaje na przykładach współczesnych polskich realizacji. W toku wykładów omawiane są zagadnienia składające się na to pojęcie, wśród nich: uwarunkowania lokalizacyjne, powierzchniowe, programowo - przestrzenne, materiałowe oraz konstrukcyjno - budowlane.

Wielkość projektowanego w czasie trwania semestru domu to około $300 \mathrm{~m}^{2}$, co odpowiada współcześnie realizowanym domom o podwyższonym standardzie. W programie użytkowym domu projektowane są: strefa dzienna (w tym: pokój dzienny z aneksem jadalnym, kuchnia ze spiżarnią, gabinet lub pokój gościnny), strefa nocna rodziców (ich sypialnia z łazienką i garderobą), oraz strefa dzieci (ich pokoje, łazienki, szafy lub garderoby). W opracowaniach projektowych rozwiązywane są również dwustanowiskowe garaże, pomieszczenia gospodarcze i techniczne - w tym kotłownia. Każdorazowo układ ten rozbudowywany jest o pomieszczenia dodatkowe, wynikające $\mathrm{z}$ indywidualnych potrzeb użytkowników. W studenckich projektach pojawiają się więc: siłownie, sale kinowe, winiarnie lub baseny.

Projekt domu jednorodzinnego obligatoryjnie rozwiązywany jest na kilku poziomach. Walorem dydaktycznym tak postawionego zadania projektowego jest konieczność rozwiązania klatki schodowej, oraz technicznego zilustrowania jej w rzutach i przekrojach. W zakresie rozwiązań budowlanych uczestnicy kursu rozwiązują wszystkie problemy materiałowe oraz konstrukcyjno - budowlane. Na rysunkach rzutów i przekroi stosują oznaczenia techniczne materiałów budowlanych. Opracowują również uproszczony opis techniczny.

Integralną częścią projektu architektonicznego jest opracowanie projektu zagospodarowania działki. Poza rysunkiem sytuacji w skali urbanistycznej (plan zagospodarowania działki 1:500), do każdego z opracowań przygotowywany jest uproszczony projekt ogrodu ${ }^{4}$, oraz detale jego wyposażenia: ogrodzenie, brama, śmietnik i altana z miejscem do grillowania.

4 Uproszczony projekt ogrodu - bez określenia gatunków nasadzeń i wymiarowania ich. 
Student poznaje również podstawowe zasady regulujące kształtowanie zurbanizowanej przestrzeni mieszkaniowej, w tym uwarunkowania prawne i planistyczne. Pomimo faktu, iż projekt przygotowywany jest jako jednostkowe „zadanie inwestycyjne”, treść wykładów obejmuje również zasady kształtowania układów zespołów domów jednorodzinnych. Do zagadnień poruszanych w tym panelu tematycznym włączono między innymi mechanizmy kształtowania osiedli strzeżonych oraz historię kształtowania tego modelu zamieszkiwania w Polsce, zilustrowaną na przykładach najistotniejszych realizacji.

W zakresie projektowania formy architektonicznej studenci zapoznawani są z zasadniczymi trendami stylistycznymi występującymi w Polsce i na świecie, w okresie od początku XX wieku. Kształcenie w tej tematyce obejmuje historię kształtowania formy domów europejskich i polskich, wznoszonych jako typowe (domy powtarzalne, tzw. domy z katalogu) jak i indywidualne (domy projektowane na zamówienie). Dodatkowe elementy tego kursu to zagadnienia z obszaru procesu inwestycyjnego i udziału w nim architekta.

Studenckie opracowania projektowe prezentowane są w formie rzutów, przekroi i elewacji, oraz widoków perspektywicznych, a także modelu, przedstawiającego obiekt wraz zagospodarowaniem działki budowlanej (1:100).

Zagadnienia związane z projektowaniem domów jednorodzinnych uzupełniane są informacjami o modelach kształtowania mieszkalnictwa interwencyjnego, rozumianego jako odpowiedź na nagłe sytuacje losowe i ekonomiczne. W panelu tym prezentowane są również teorie budownictwa rosnącego - pozwalającego na rozbudowę domu wraz z poprawą statutu finansowego rodziny.

Uzupełnienie treści podstawowych kursu stanowią zagadnienia zgrupowane w bloku określonym jako „dom drugi”. Omawiane są w nim zarówno polskie domy wakacyjne i letniskowe jak również ich odpowiedniki w rożnych krajach europejskich. Studenci poznają polskie ośrodki wczasowe z domkami campingowymi, jak i holenderskie „miasteczka” przyczep campingowych czy hiszpańskie zespoły domów wakacyjnych.

\section{BUDYNEK WIELORODZINNY (SEMESTR IV)}

Kurs dydaktyczny w zakresie kształtowania zabudowy mieszkaniowej wielorodzinnej podzielony jest na trzy części. Każdej z nich przyporządkowane są treści teoretyczne - realizowane w formie wykładów i seminariów, oraz praktyczne - stanowiące zadania klauzurowe i projektowe. Kształcenie to podzielone jest na: mieszkanie (pojedynczy lokal mieszkalny), budynek (obiekt budowlany wraz z wyposażeniem i zagospodarowaniem jego działki) oraz osiedle (zespół inwestycji z obszaru mieszkalnictwa wielorodzinnego w skali urbanistycznej). Kurs uzupełniany jest zagadnieniami omawianymi wyłącznie w czasie wykładów. Dotyczą one przede wszystkim form mieszkalnictwa zbiorowego. Wśród omawianych i prezentowanych zagadnień są hotele w różnym standardzie, bursy i akademiki, domy dla osób starszych i domy zakonne oraz domy dziecka i więzienia.

Kształcenie $\mathrm{w}$ zakresie projektowania mieszkań prowadzone jest na podstawie pojęć i zagadnień z obszaru teorii architektury. Studenci poznają typologię mieszkań prowadzoną w oparciu o układy komunikacyjne (mieszkania o układach: amfiladowych, rozkładowych i cyrkulacyjnych) oraz układy funkcjonalne (mieszkania z podziałem na strefy funkcjonalne i bez takiego podziału). Poznają również różnice pomiędzy układami jedno i kilku poziomowymi. W odniesieniu do wszystkich układów poznają ich rys historyczny, najbardziej charakterystyczne przykłady oraz realizacje współczesne. Każdorazowo naświetlane są wady i zalety poszczególnych rozwiązań. Ich wartościowanie odbywa się w oparciu o ocenę układów funkcjonalnych oraz preferencje użytkowników. Wykłady z zakresu teorii projektowania mieszkań obejmują również obszar przepisów prawa. Szeroki ich zakres prezentowany jest na podstawie konkretnych przykładów - rzutów mieszkań zaczerpniętych z ofert mieszkaniowych deweloperów. Studenci zapoznawani są z realizacjami modelowymi oraz takimi, w których 
poszczególne przepisy są łamane. W trakcie wykładów prezentowane są również mieszkania wzniesione w różnych standardach użytkowych: socjalnym, powszechnym, podwyższonym i luksusowym. Wprowadzona gradacja założona została na podstawie ceny psychologicznej mieszkań. Omawiane są również mieszkania zrealizowane w okresie PRL. Studenci zapoznawani są z obowiązującymi wówczas normatywami mieszkaniowymi, technologią wznoszenia budynków i zasadami przydziału mieszkań.

Zajęcia praktyczne z zakresu projektowania mieszkań prowadzone są jako ćwiczenia klauzurowe. Studenci wykonując je opracowują rzuty mieszkań zlokalizowane w różnych budynkach, o różnym standardzie użytkowym oraz przeznaczone do zamieszkania przez różną liczbę osób. Podstawę opracowań stanowi mieszkanie przeznaczone dla czteroosobowej rodziny o powierzchni około $70 \mathrm{~m}^{2}$. Wśród zadań klauzurowych pojawia się ono jako zlokalizowane w: budynku punktowym (mieszkanie narożne), budynku klatkowym - sekcyjnym (mieszkanie „na przestrzał”) oraz budynku galeriowym. Rozwiązywane jest również jako dwupoziomowe, zlokalizowane w różnych typach budynków wielorodzinnych. Każde z projektowanych mieszkań opracowywane jest w oparciu o doświadczenia projektowe, wynikające z opracowania domu atrialnego. Każde posiada również tak zwany element „przedłużenia” mieszkania - ogródek, balkon, logię, bądź taras zlokalizowany na dachu.

Drugi z etapów kształcenia w zakresie budownictwa wielorodzinnego dotyczy budynku. Studenci zapoznawani są z historią zamieszkiwania w domach czynszowych oraz ich charakterystycznymi, historycznymi modelami. Szczególny nacisk w tym zakresie kładziony jest na zagadnienia związane z nasłonecznieniem i przewietrzaniem mieszkań w poszczególnych typach budynków (klatkowym, sekcyjnym, punktowym, galeriowym i korytarzowym). Prezentowane są walory i wady poszczególnych układów komunikacji oraz najbardziej charakterystyczne przykłady obiektów zrealizowanych.

Wykłady poświęcone rozwiązaniom formalnym prowadzone są w oparciu o przykłady zróżnicowane pod względem stylistyki architektonicznej, co pozwala studentom zrozumieć przewartościowania poglądów estetycznych, charakterystycznych dla architektury mieszkaniowej XX i XXI wieku. Prezentowane realizacje odzwierciedlają również różny w różnych okresach sposób podejścia do własności ziemi i poczucia prywatności. Prowadzący nie wartościują konkretnych rozwiązań. Wskazują natomiast ich wady i zalety. Problematyka, która jest realizowana $\mathrm{w}$ czasie trwania tego kursu dotyczy również obszaru norm, przepisów prawa i zasad wynikających z tzw. dobrych wzorów. Studenci zapoznawania są z całym szeregiem zasad kierujących projektowaniem budynków wielorodzinnych. Wśród nich na czoło wysuwają się te, które dotyczą klatek schodowych. Ich złożona problematyka, związana z dostępnością przez osoby niepełnosprawne oraz komfortem użytkowania mieszkańców. Zagadnienia te dotyczą również wyposażenia i sposobu zagospodarowania działki budowlanej.

Zasadniczym tematem semestralnych opracowań studenckich jest zabudowa mieszkaniowa zlokalizowana na teoretycznej działce budowlanej - kwartale miejskim, otoczonym komunikacją. Zadanie projektowe polega na opracowaniu projektu budynku, zintegrowanego z nim garażu podziemnego oraz zagospodarowaniu terenu inwestycji (plac zabaw dla dzieci, miejsca wypoczynkowe i rekreacyjne, parkingi naziemne, miejsce gromadzenia odpadów stałych i trzepak). Wszystkie działania projektowe muszą być prowadzone w zgodzie z obowiązującymi przepisami, oraz w sposób prawidłowy pod względem budowlanym i konstrukcyjnym. Forma proponowanych rozwiązań architektonicznych każdorazowo stanowi indywidualną wypowiedź autorską. Jej zadaniem jest wpisanie się w konkretną stylistykę estetyczną, określoną przez studenta na podstawie inspiracji projektowych. Autorzy zakładają również standard materiałowy i tym samym ekonomiczny przyjętych rozwiązań. Decyzja to określa grupę docelową (target), do której inwestycja jest adresowana. Ma również bezpośrednie przełożenia na standard powierzchniowy i programowy proponowanych mieszkań.

Grafika opracowania projektowego podzielona jest na dwie części: techniczną i developerską. Studenci opracowują: rzuty kondygnacji, detale mieszkań i stref wejść do klatek 
schodowych, rzut garażu podziemnego i dachu budynku oraz stosowne przekroje i elewacje, ponadto rysunek projektu zagospodarowania działki, dla której opracowywany jest bilans powierzchni. Rysunki te sporządzane są $\mathrm{w}$ formie koncepcyjnej. Wszystkie proponowane rozwiązania muszą być opracowane na poziomie technicznym. W czasie trwania zajęć projektowych studenci sporządzają również projekt placu zabaw i terenu rekreacyjnego. Mają one być obiektami indywidualnymi, wyposażonymi niestandardowo. Ponadto opracowują planszę reklamową promującą przygotowane opracowania. Zawiera ona widoki perspektywiczne budynku, rzuty wybranych mieszkań wraz z ich aranżacjami meblowymi, oraz schematy rzutów wszystkich kondygnacji budynku (budynków) zaprojektowanego na działce z określeniem ilości i podaniem powierzchniami poszczególnych typów mieszkań.

Ostatni z etapów kształcenia w zakresie mieszkalnictwa wielorodzinnego dotyczy sfery urbanistyki. W czasie wykładów i seminariów prezentowane są teorie, które stały się podstawą kształtowania środowiska mieszkaniowego w miastach od połowy wieku XIX do chwili obecnej. Prezentowane są również europejskie i polskie realizacje z tego okresu. Szczególna uwaga zwrócona jest na wielorodzinne osiedla mieszkaniowe, zrealizowane w Polsce (w tym w Lublinie po II wojnie światowej). Na tle zasad programowania zespołów mieszkaniowych z okresu PRL (w tym zasad kształtowania Strukturalnej Jednostki Mieszkaniowej), prezentowane są współczesne metody projektowania. Analizy historycznych osiedli dotyczą ich kompozycji urbanistycznej, układu komunikacyjnego, wyposażenia usługowego i programu terenów rekreacyjnych. Prowadzone zajęcia mają na celu zainspirowanie studentów do własnych, krytycznych analiz realizacji współczesnych. W tym odniesienia się do tak zwanych „osiedli za murami”, współczesnych gett wydzielanych w strukturach miejskich.

Kurs kończy się opracowaniem makiety „współczesnego miasta”, złożonej z szeregu prac poszczególnych autorów. Studenci sami decydują o wyborze „sąsiedztwa” swych opracowań projektowych (makiety kwartałów zabudowy w skali 1:200). Wspólnie (w oparciu o szacowaną liczbę mieszkańców) opracowują program usług i wskazują optymalne miejsca ich lokowania. W wyniku dyskusji studenci oceniają zaproponowane przez siebie formy w kontekście propozycji kolegów. Doświadczenie to odpowiada rzeczywistym realizacjom prowadzonym przez deweloperów, którzy na sąsiednich działkach, w oparciu o takie same zapisy planu miejscowego (wytyczne do projektu kursowego), kreują skrajnie różne rozwiązania stylistyczne. Dotyczy to w szczególności typu budynków oraz ich wysokości. Podsumowanie tych dyskusji stanowią próby sformułowania zapisów miejscowego planu zagospodarowania przestrzennego - takie, które będą gwarantowały ład przestrzenny oraz wyposażenie odpowiadające potrzebom społecznym mieszkańców.

\section{PRACE DYPLOMOWE}

Absolwenci szkół architektury w toku swej dydaktyki opracowują obecnie dwa projekty dyplomowe inżynierski i magisterski. Prace związane z mieszkalnictwem stanowią tematy często podejmowane. Wśród najczęściej realizowanych opracowań wymienić należy: domy jednorodzinne, rezydencje, zespoły zabudowy pośredniej, rodzinne domy dziecka i domy specjalne (na przykład interwencyjne lub rosnące) - na poziomie inżynierskim oraz: budynki i zespoły zabudowy wielorodzinnej a także domy studenta, hotele i więzienia - na poziomie magisterskim.

Dyplom inżynierski to opracowanie techniczne, wieńczące cykl dydaktyczny studiów I stopnia. Przyszły inżynier opracowuje projekt dyplomowy składający się z dwóch integralnych części: praktycznej (rysunkowej) oraz części teoretycznej (opisowej). Zakres opracowania projektu jest zbliżony do sposobu prezentacji dokumentacji technicznej składanej do pozwolenia na budowę. Rysunki projektu w tym: orientacja, projekt zagospodarowania działki, rzuty, przekroje, elewacje i detale wzbogacone są o widoki perspektywiczne. Opracowanie prezentowane jest na planszach i stanowi spójną całość. Projekt uzupełnia model. Część 
teoretyczna każdorazowo zawiera: wprowadzenie w tematykę pracy, opis lokalizacji projektu oraz analizy uwarunkowań projektowych. Integralną część pracy stanowi opis techniczny do projektu zagospodarowania działki oraz projektu budynku.

Dyplom magisterski zamykający II stopień studiów to opracowanie wyrażające klarowną ideę twórczą oraz rozwiązujące skomplikowane problemy projektowe. Mieszczą się one w obszarze urbanistyki lub funkcji obiektu. Program przestrzenny autor opracowuje bazując na analizie współczesnych budynków o zbliżonej funkcji. Główne wytyczne formalne definiowane są w oparciu o inspiracje projektowe. Dyplomant powinien wykazać ich związek z własną pracą. Opracowanie pisemne wykracza poza zakres pracy inżynierskiej. Wzbogacone jest o szerokie studia literatury tematu z obszaru teorii architektury, oraz dziedzin i dyscyplin związanych z problematyką pracy. Ich celem jest zdefiniowanie założeń i idei projektowych. W oparciu o przeprowadzone studia bibliograficzne dyplomant uzasadnia i argumentuje własne decyzje projektowe. Dowodzi tym samym umiejętności świadomego działania projektowego, w zgodzie z przyjętymi wartościami. Opracowanie dyplomowe, podobnie jak projekt inżynierski, przedstawiane jest w formie plansz, modelu oraz opisu. Istotnym elementem jest poziom opracowania graficznego, jego czytelność, kompletność oraz merytoryczna zgodność $\mathrm{z}$ ideą projektową. Zadanie to przygotowuje absolwenta do pracy $\mathrm{w}$ zawodzie architekta, w szczególności do udziału w konkursach architektonicznych.

\section{PODSUMOWANIE}

Zaprezentowany model kształcenia w zakresie projektowania obiektów mieszkaniowych, wypracowany na Wydziale Budownictwa i Architektury Politechniki Lubelskiej praktykowany jest od szeregu lat, w zasadzie od początku dydaktyki w zakresie architektury w Politechnice Lubelskiej. Kolejne etapy kształcenia rozwijają wiedzę studenta. Kolejne zadania projektowe stawiają nowe, coraz to bardziej złożone wyzwania. Przy ich realizacji każdorazowo poszerzany jest zakres problemowy, stopień opracowania technicznego oraz graficznego projektu.

Efekty przyjętej metody kształcenia weryfikuje rynek. Opinie pracodawców zatrudniających absolwentów WBiA PL są tego najlepszym dowodem.

\section{PIŚMIENNICTWO}

Cybis J., 2006. Ksztatcenie architektoniczne - indoktrynacja czy neutralność estetyczna?, [w:] Nauka - Architektura - Edukacja, praca zbiorowa pod redakcją: J.C. Żarnowieckiej i A. Owerczuka, Wydawnictwo Politechniki Białostockiej, Białystok .

Kłopotowski M., 2006. Dom. O projekcie idealnym studenta II roku, [w:] Nauka - Architektura - Edukacja, praca zbiorowa pod redakcją: J.C. Żarnowieckiej i A. Owerczuka, Wydawnictwo Politechniki Białostockiej, Białystok.

Kucza-Kuczyński K., 2006. Rozterki nauczyciela architektury, [w:] Nauka - Architektura - Edukacja, praca zbiorowa pod redakcją: J.C. Żarnowieckiej i A. Owerczuka, Wydawnictwo Politechniki Białostockiej, Białystok.

Kuryłowicz E., 2006. Architektura na tle kultury. Miejsce teorii krytycznej w nauczaniu projektowania architektonicznego w interpretacji Pracowni Projektowania i Teorii Architektury na WA PW [w:] Nauka - Architektura - Edukacja, praca zbiorowa pod redakcją: J.C. Żarnowieckiej i A. Owerczuka, Wydawnictwo Politechniki Białostockiej, Białystok.

Wilamowska M. (red.), 2000. Dom przyszłości. Konkurs Wydawnictwa MURATOR i Fundacji DOM DOSTĘPNY, Wydawnictwo MURATOR, Warszawa.

Włodarczyk J.A., 1997. Żyć znaczy mieszkać. Dom naszych pragnień i możliwości, Wydawnictwo Naukowe PWN, Warszawa - Kraków. 


\section{THE HOUSING INDUSTRY IN DIDACTICS}

Abstract. In the Faculty of Civil Engineering and Architecture at the Lublin University of Technology, teaching of the object designs - residential areas- is a multistage tutoring process covering three basic design tasks (flat, house, multi-occupied building) With each realization, the scope of a problem as well as a degree of technical and graphic insight are being extended. Residential objects (different in function size) are also often chosen to be a subject of the theses on engineering and master's level. Below is a methodology of teaching the abovementioned issues at the Lublin University of Technology

Key words: multi-occupied building, atrial house, detached house, flat, complex of detached houses, multi-occupied building development. 